\title{
Effects of Co-Existing Ions on the Phosphorus Potassium Ratio of the Precipitate Formed in the Potassium Phosphate Crystallization Process
}

\section{Hiroyuki Harada1*, Yumi Katayama1, Asmak Afriliana², Minori Inoue ${ }^{1}$, Ryota Teranaka1, Yoshiharu Mitoma1}

${ }^{1}$ Faculty of Environmental Science, Prefectural University of Hiroshima, Hiroshima, Japan

${ }^{2}$ Faculty of Agricultural Technology, Univerity of Jember, Jember, Indonesia

Email: ^ho-harada@pu-hiroshima.ac.jp

How to cite this paper: Harada, H., Katayama, Y., Afriliana, A., Inoue, M., Teranaka, R. and Mitoma, Y. (2017) Effects of Co-Existing Ions on the Phosphorus Potassium Ratio of the Precipitate Formed in the Potassium Phosphate Crystallization Process. Journal of Environmental Protection, 8, 1424-1434.

https://doi.org/10.4236/jep.2017.811086

Received: September 18, 2017

Accepted: October 28, 2017

Published: October 31, 2017

Copyright $\odot 2017$ by authors and Scientific Research Publishing Inc. This work is licensed under the Creative Commons Attribution International License (CC BY 4.0).

http://creativecommons.org/licenses/by/4.0/

\begin{abstract}
Livestock wastewater is mainly treated with activated sludge, but ions such as phosphorus, potassium, ammonium, nitrate and sulfate remain in the effluent. In this study, the effects of residual ions on phosphorus recovery using the magnesium potassium phosphate crystallization method were investigated when magnesium was added to increase the $\mathrm{pH}$. If co-existing ions affect the products, the phosphorus to potassium molar ratio (K/P ratio) of the precipitate will deviate from being equimolar. Artificial wastewater test solutions containing $5.6-20.3 \mathrm{mM}$ ammonium, $25.6 \mathrm{mM}$ potassium, $6.5 \mathrm{mM}$ phosphorus, 0 - $7.35 \mathrm{mM}$ nitrate, and $0-3.06 \mathrm{mM}$ sulfate were used. First, the optimum operating $\mathrm{pH}$ and amount of magnesium added to give a high phosphorus removal rate and recovery rate were determined. The experimental setup was a $10 \mathrm{~L}$ aerated and stirred reactor, and a $5 \mathrm{~L}$ settling tank. The K/P ratio in precipitate was approximately 1 using the optimum conditions. Continuous $2 \mathrm{~h}$ treatment allowed a white precipitate containing about $30 \mathrm{~g}$ of needle-like crystals to be obtained. Next, the effects of varying the ammonium, nitrate, and sulfate ion concentrations in the artificial effluent were investigated. Ammonium and sulfate ion concentrations of $8 \mathrm{mM}$ or more and 3 $\mathrm{mM}$ or more, respectively, caused the $\mathrm{K} / \mathrm{P}$ ratio to decrease to about 0.7 and 0.5 , respectively. Varying the nitrate concentration did not affect the K/P ratio, even at a nitrate concentration of $7.35 \mathrm{mM}$.
\end{abstract}

\section{Keywords}

Magnesium Potassium Phosphate, Ammonium, Sulfate, Nitrate, K/P Ratio, 
pH, hComponent, Formatting, Style, Styling

\section{Introduction}

Modern agricultural systems require phosphorus compounds to be applied in fertilizers, but the raw materials required (phosphorus ores) are likely to be exhausted at current rates of use. According to Kuroda et al., The $80 \%$ of the phosphorus ore that is extracted is currently used in fertilizers [1]. Consumption is currently increasing at $3 \%$ each year. If consumption continues to increase at this rate, consumption in the 2060s will be about five times current consumption. This will result in economically minable phosphorus ore reserves being depleted. A realistic scenario is that $50 \%$ of currently minable ore reserves will still be available in the 2060s. Japan relies on imported phosphorus ore [1]. It is therefore desirable for techniques for recovering $\mathrm{P}$ from waste to be developed to decrease the risk of ore reserves being depleted and decrease the reliance of Japan on imported phosphate ore. Techniques for recovering phosphorus currently discharged into the environment are required to prevent environmental degradation. Livestock wastewater contains high concentrations of phosphorus, so it is easy to study phosphorus recovery methods using livestock wastewater. A traditional livestock wastewater treatment process is shown in Figure 1. First, solids, such as feces, in the wastewater are separated from the liquid. The liquid is then treated with activated sludge, which decomposes the organic substances and nitrifies the ammonium, turning some into nitrate. Even after these treatments the liquid will contain a high concentration of phosphorus.

The ammonia concentration is high at the start of the biological treatment process, so phosphorus can be recovered as magnesium ammonium phosphate (MAP; $\mathrm{MgNH}_{4} \mathrm{PO}_{4}$ ) using coexisting $\mathrm{Mg}$. The crystallization of MAP is caused by a reaction among $\mathrm{PO}_{4}^{3-}, \mathrm{NH}_{4}^{+}$, and $\mathrm{Mg}^{2+}$ in aqueous solution. The reaction is shown in formula (1).

$$
\mathrm{Mg}^{2+}+\mathrm{NH}_{4}^{+}+\mathrm{PO}_{4}^{3-} \rightarrow \mathrm{MgNH}_{4} \mathrm{PO}_{4}
$$

The MAP precipitation method is used for liquids containing $\mathrm{P}$ and ammonium. $\mathrm{Mg}^{2+}$ is added to generate MAP in weak alkaline solutions. The MAP method gives a high crystal formation rate, so crystallization occurs without seeding. This MAP method can be used at $\mathrm{pH} 8.5$ to $\mathrm{pH}$ 9. The MAP method is of-

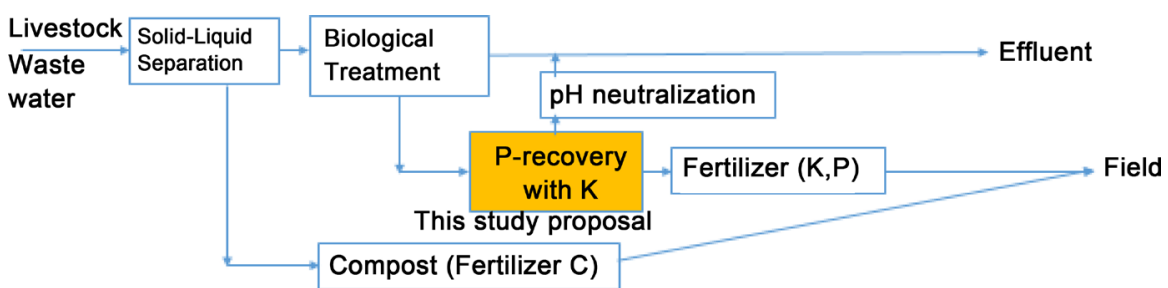

Figure 1. Schematic representation of a traditional livestock wastewater treatment process. 
ten used for solutions containing relatively high $\mathrm{P}$ or ammonium concentrations, such as livestock wastewater and side stream wastewater produced during activated sludge treatments [2]-[7].

The ammonium concentration will decrease and MAP treatment will be difficult when a long treatment time is used and the nitrification efficiency is high. In this study, we investigated the recovery of phosphorus as magnesium potassium phosphate (MPP) through the reaction shown in formula (2) using a high potassium concentration.

$$
\mathrm{Mg}^{2+}+\mathrm{K}^{+}+\mathrm{PO}_{4}^{3-} \rightarrow \mathrm{MgKPO}_{4}
$$

The MPP crystallization method has been used for wastewater with a high phosphorous concentration (30 $\mathrm{mM}$ or more, e.g., in urine) and a high potassium concentration [8]. Wastewater treated using activated sludge contains a low ammonium concentration, so it is difficult to use the MAP method to remove phosphorous from treated water. However, the relatively high $\mathrm{K}$ concentrations in wastewater treated using activated sludge can be appropriate for MPP treatment. The MPP treatment method has been used to remove relatively low phosphorus concentrations from wastewater treated using activated sludge in very few studies. The optimum $\mathrm{pH}$ for MPP treatment depends on the target phosphorous concentration because hydroxy ions are involved in the solubilities of the products. The optimum $\mathrm{pH}$ for treating wastewater containing $30 \mathrm{mM} \mathrm{P}$ in synthetic urine to give an equimolar precipitate of $\mathrm{P}, \mathrm{Mg}$, and $\mathrm{K}$ is $\mathrm{pH} 8$ [8] [9], and the optimum $\mathrm{pH}$ for treating synthetic wastewater containing 7.6 $\mathrm{mM} \mathrm{P}$ is $\mathrm{pH} 10$ [10]. In the study described here, a $\mathrm{P}$ concentration of $6.5 \mathrm{mM}$ was used to approximate the typical concentration in livestock wastewater, and the effects of the $\mathrm{pH}, \mathrm{Mg}$ dosage, and coexisting substances on the formation of MPP were investigated using an experimental system that consisted of a reactor and a settling tank. The synthetic wastewater was designed to simulate effluent from piggery wastewater treated with activated sludge [11].

\section{Methods}

\subsection{Apparatus and Standard Experimental Conditions}

The experimental setup is shown in Figure 2. The system consisted of a $5 \mathrm{~L}$ raw water storage tank, a $10 \mathrm{~L}$ reaction tank, and a $5 \mathrm{~L}$ sedimentation tank. The synthetic livestock wastewater (containing potassium chloride, sodium dihydrogenphosphate, and ammonium chloride) in the raw water tank was fed into the reaction tank at a flow rate of $7.7 \mathrm{~L} / \mathrm{h}$. A dosage $\mathrm{Mg} / \mathrm{P}$ as phosphate $\left(\mathrm{PO}_{4}-\mathrm{P}\right) \mathrm{mo}-$ lar concentration ratio of 1 was maintained in the reactor tank by feeding a solution containing $50 \mathrm{mM}$ magnesium chloride into the reaction tank at a rate of $1.5 \mathrm{~L} / \mathrm{h}$ throughout the $2 \mathrm{~h}$ treatment process. The mixture was stirred and aerated using an air pump supplying air at a rate of $30 \mathrm{~L} / \mathrm{h}$ throughout the treatment process. The basic synthetic wastewater contained $\mathrm{K}, \mathrm{PO}_{4}-\mathrm{P}$, and $\mathrm{NH}_{4}^{+}$at concentrations of $25.6 \mathrm{mM}, 6.5 \mathrm{mM}$, and $5.6 \mathrm{mM}$, respectively, and the $\mathrm{pH}$ was 7.5. 


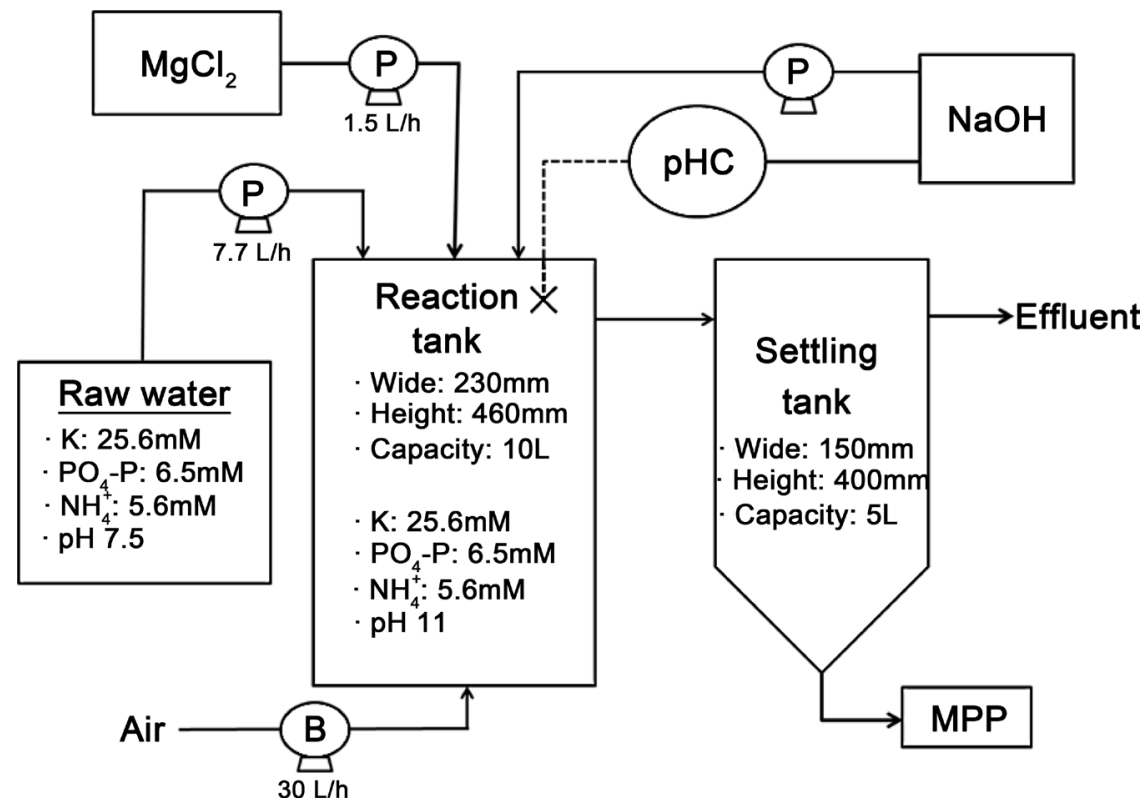

Figure 2. Experimental setup.

\subsection{Effects of Varying the $\mathrm{pH}$ and $\mathrm{Mg}$ Dosage on the Formation of MPP}

The $\mathrm{pH}$ of the solution in the reactor was varied between $\mathrm{pH} 8$ and $\mathrm{pH} 12$ using a $\mathrm{pH}$ controller. The dosage $\mathrm{Mg} / \mathrm{P}$ ratio was changed from 1 to 2 by changing the rate at which magnesium chloride solution was added.

\subsection{Effects of Coexisting Substances}

Tests were performed using ammonium concentrations of $8.36 \mathrm{mM}, 11.4 \mathrm{mM}$, and $22.3 \mathrm{mM}$ at the standard conditions. Tests were also performed at nitrate concentrations of $0 \mathrm{mM}, 4.02 \mathrm{mM}$, and $8.04 \mathrm{mM}$, and at sulfate concentrations of $1.02 \mathrm{mM}, 2.04 \mathrm{mM}$, and $3.06 \mathrm{mM}$.

\subsection{Precipitate}

The white precipitate that formed in the reaction tank was moved to the settling tank in the overflowing solution and settled in the cone of the sedimentation tank. After a reaction, the mixture was allowed to stand for a specified time, then the reaction solution in the settling tank was passed through a filter. The white precipitate adhering to the filter paper was dried for $24 \mathrm{~h}$ in flowing air at $60^{\circ} \mathrm{C}$. The filtrate was passed through a $0.45 \mu \mathrm{m}$ membrane filter.

\subsection{Analysis}

The Magnesium concentrations in the samples were determined using an AA6300 atomic absorption spectrometer (Shimadzu, Kyoto, Japan). The potassium and sodium concentrations were measured by flame photometry using the same atomic absorption spectrometer. The phosphate and ammonium concentrations were measured using the molybdenum blue and ascorbic acid method and using 
the indophenol method, respectively, and a V-530 ultraviolet-visible spectrophotometer (JASCO, Halifax, Canada) [12]. The precipitates were inspected using an ECLIPSE E-600 optical microscope (Nikon, Tokyo, Japan) and a JSM6510 A scanning electron microscope (JEOL, Tokyo, Japan). The crystals were analyzed using energy dispersive X-ray spectrometry (EDS) using an EDX-LE instrument (Shimadzu, Kyoto, Japan).

\section{Results and Discussion}

\subsection{Optimum pH}

The MPP crystallization method can be used as a post-treatment for effluent treated with activated sludge, so we assessed the effects of the presence of nitrate, ammonium, and sulfate ions on the MPP production process. Table 1 and Figure 3 shows the Effects of $\mathrm{pH}$ control in component of precipitate, and Electron microscopy images of crystals produced. These components $\mathrm{Mg}, \mathrm{P}, \mathrm{K}$ of the crystals were almost equimolar at $\mathrm{pH} 11$. Needle-like crystals peculiar to MAP and MPP were found at $\mathrm{pH} 9$ or higher, but at $\mathrm{pH} 12$ the components of the crystals stopped being equimolar because too much sodium hydroxide was present.

Needle-like crystals not seen at $\mathrm{pH} 8$ became visible at $\mathrm{pH} 9$, and the needle length increased and more needle-like crystals were present at higher $\mathrm{pH}$ values. The decreases in the $\mathrm{P}$ and $\mathrm{K}$ concentrations in the liquid increased as the $\mathrm{pH}$ increased from $\mathrm{pH} 8$ and reached a maximum at $\mathrm{pH} 11$, but then decreased when the $\mathrm{pH}$ was increased to $\mathrm{pH} 12$. Figure 4 shows the decreases in the concentrations of the components of the solution at different $\mathrm{pH}$.

The amount by which the Mg concentration decreased did not decrease between $\mathrm{pH} 11$ and $\mathrm{pH} 12$, and the ammonium concentration remained almost constant.

Table 1. Effects of pH control in component of precipitate.

\begin{tabular}{cccc}
\hline $\mathrm{pH}$ & Dosage Mg:P ratio & $\mathrm{Mg} / \mathrm{P}$ (precipitate) & $\mathrm{K} / \mathrm{P}$ (Preecipitate) \\
\hline 8 & $1: 1$ & 0.86 & 0.34 \\
9 & $1: 1$ & 0.71 & 0.50 \\
10 & $1: 1$ & 0.79 & 0.77 \\
11 & $1: 1$ & 0.84 & 0.99 \\
12 & $1: 1$ & 1.36 & 0.78 \\
\hline
\end{tabular}

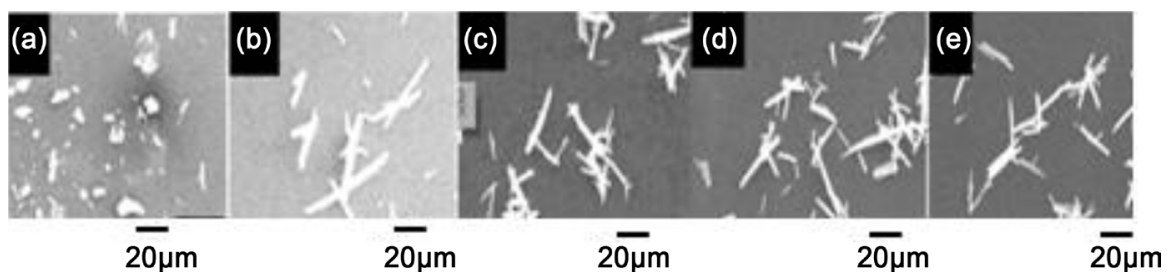

Figure 3. Electron microscopy images of crystals produced at different $\mathrm{pH}$ values. ((a) $\mathrm{pH}$ 8; (b) $\mathrm{pH} 9$; (c) $\mathrm{pH} \mathrm{10;} \mathrm{(d)} \mathrm{pH} 11$; (e) $\mathrm{pH} 12$ ). 


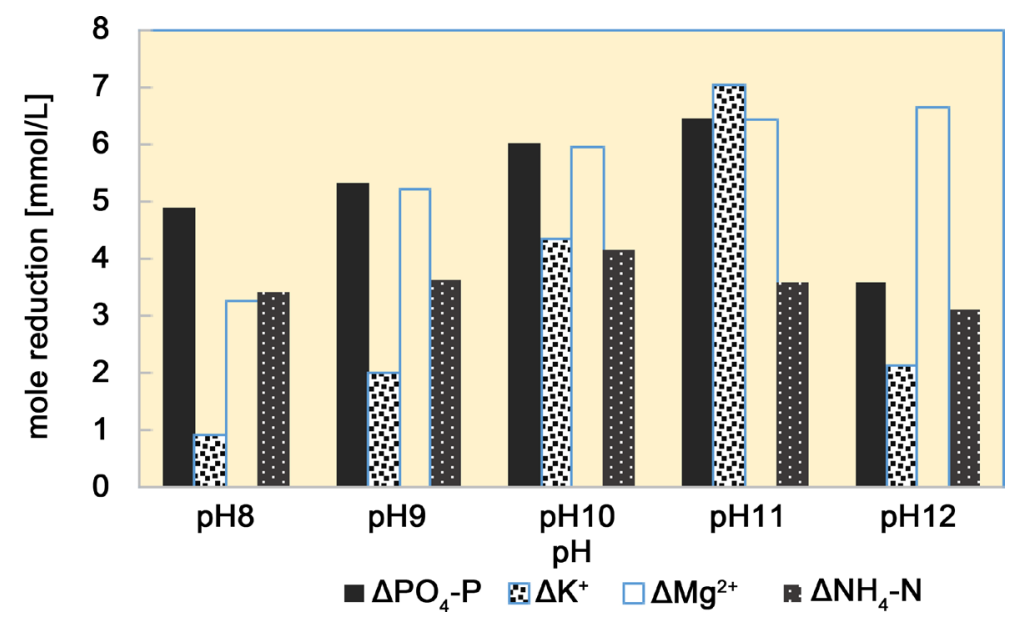

Figure 4. Decreases in the concentrations of the components of the solution at different $\mathrm{pH}$.

Table 2. Phosphorus removal ratios and recovery ratios at different $\mathrm{pH}$ values.

\begin{tabular}{cccccc}
\hline $\mathrm{pH}$ & 8 & 9 & 10 & 11 & 12 \\
Removal rate (\%) & 74.8 & 82.0 & 92.5 & 98.8 & 55.1 \\
Recovery rate (\%) & 93.2 & 96.1 & 97.7 & 95.5 & 99.7 \\
\hline
\end{tabular}

At $\mathrm{pH} 11$, the decreases in the phosphorous potassium, and magnesium Concentrations in the liquid were almost equimolar. The molar ratios of the precipitates, determined by EDS, were 0.84 and 0.95 , and the ammonium and sodium contents were $4 \%$ and $8 \%$, respectively. It therefore seems that the contents of the components of the precipitate reflected the decreases in the concentrations of the components of the solution. We will examine this using the removal rate and recovery rate using the equations below [13].

$$
\begin{aligned}
& \text { Recovery rate of } \mathrm{PO}_{4}-\mathrm{P}=\frac{\mathrm{PO}_{4}-\mathrm{P} \text { in white precipitate }}{\mathrm{PO}_{4}-\mathrm{P} \text { decrement }} \\
& \text { Recovery rate of } \mathrm{PO}_{4}-\mathrm{P}=\frac{\mathrm{PO}_{4}-\mathrm{P}_{\text {initial }}-\mathrm{PO}_{4}-\mathrm{P}_{\text {equilibrium }}}{\mathrm{PO}_{4}-\mathrm{P}_{\text {initial }}}
\end{aligned}
$$

The results are shown in Table 2. The removal rate and recovery rate at $\mathrm{pH} 10$ and $\mathrm{pH} 11$ were $90 \%$ or higher. Finer crystals were produced at $\mathrm{pH} 11$ than at $\mathrm{pH} 10$, and this may have caused the recovery rates at $\mathrm{pH} 10$ and $\mathrm{pH} 11$ to be different. However, the difference was slight, so we conducted further tests at $\mathrm{pH}$ 11.

\subsection{Optimum Dosage Magnesium}

The effects of the magnesium dosage on the three components are shown in $\mathrm{Ta}$ ble 3. The magnesium content of the precipitate was higher at a dosage $\mathrm{Mg} / \mathrm{P}$ ratio of 1.3 than at lower ratios because magnesium hydroxide was precipitated. It appeared that the optimum magnesium concentration was the same as the phosphorus concentration. 


\subsection{Results of Operating the System}

Further tests were performed at $\mathrm{pH} 11$ using an $\mathrm{Mg} / \mathrm{P}$ molar concentration ratio of 1 . The results obtained when the water quality was varied are shown in Table 4 , and the results of the EDS analyses and the molar ratios found when acid dissolution was performed are shown in Figure 5.

An electron microscopy photograph of the precipitate is shown in Figure 6. Both the numbers of atoms (determined by EDS) and the results of the acid dissolution analyses also indicated that the K/P molar ratios were almost 1 and that some ammonium and sodium were included in the precipitates.

\subsection{Effects of Ammonium on the Formation of MPP}

In our simple batch tests, ammonium concentrations up to about $5 \mathrm{mM}$ did not affect the formation of MPP, and the K/P molar concentration ratios in the crystals were close to 1 [14]. The effects of varying the initial ammonium concentration on the formation of MPP were examined. The effects of varying the

Table 3. Effects of the magnesium dosage on the Mg:P molar concentration ratio in precipitate.

\begin{tabular}{cccc}
\hline $\mathrm{pH}$ & Dosage Mg:P ratio & $\mathrm{Mg} / \mathrm{P}$ (precipitate) & $\mathrm{K} / \mathrm{P}$ (Preecipitate) \\
\hline 11 & $1.01: 1$ & 0.86 & 0.34 \\
11 & $1.3: 1$ & 0.71 & 0.5 \\
11 & $1.7: 1$ & 0.79 & 0.77 \\
11 & $2.01: 1$ & 0.84 & 0.99 \\
\hline
\end{tabular}

Table 4. Water quality parameters before and after the reactor process and in the settling tank and for the effluent.

\begin{tabular}{|c|c|c|c|c|}
\hline \multirow{2}{*}{ Components } & \multicolumn{2}{|c|}{ Concentration $(\mathrm{mM})$ in the reaction tank } & \multirow{2}{*}{$\begin{array}{l}\text { Concentration }(\mathrm{mM}) \\
\text { in the settling tank }\end{array}$} & \multirow{2}{*}{$\begin{array}{c}\text { Concentration }(\mathrm{mM}) \\
\text { in the effluent }\end{array}$} \\
\hline & Before the treatment & After the treatment & & \\
\hline $\mathrm{PO}_{4}-\mathrm{P}$ & 6.48 & 0.21 & 0.16 & 0.14 \\
\hline $\mathrm{K}$ & 25.6 & 18.8 & 19.0 & 19.6 \\
\hline $\mathrm{Mg}$ & 0.07 & 0.44 & 0.23 & 0.15 \\
\hline $\mathrm{NH}_{4}^{+}-\mathrm{N}$ & 5.6 & 2.82 & 2.82 & 2.92 \\
\hline
\end{tabular}

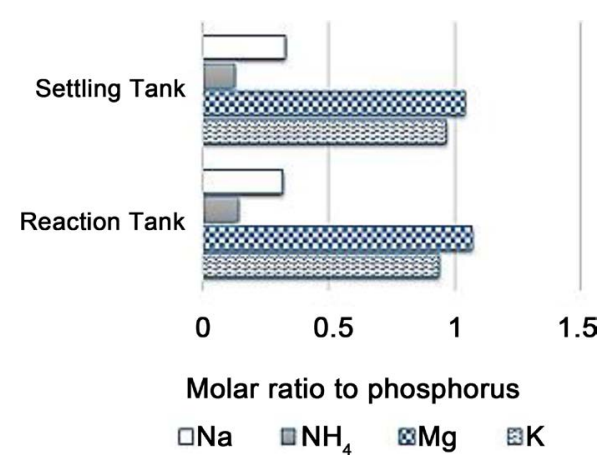

Figure 5. Results of the acid dissolution analyses of the components of the crystals. 

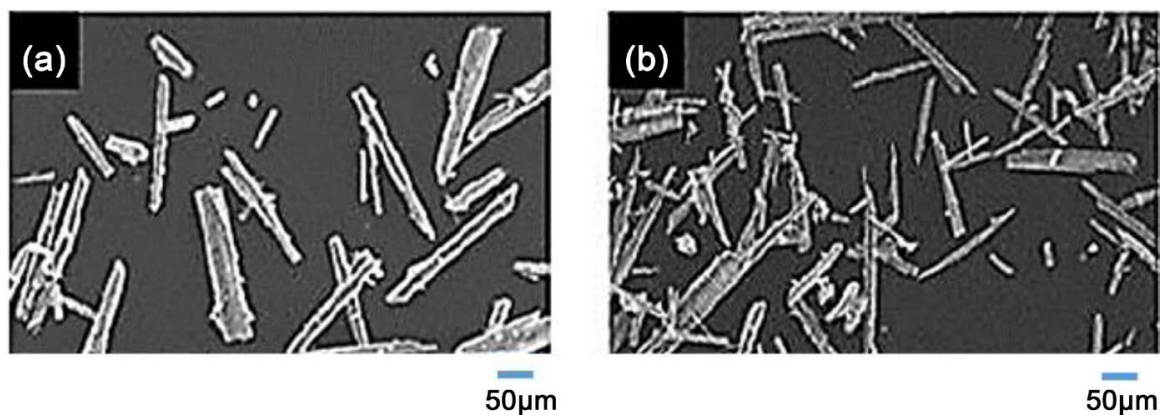

Figure 6. Electron micrographs of the crystals in (a) the reactor and (b) the settling tank.

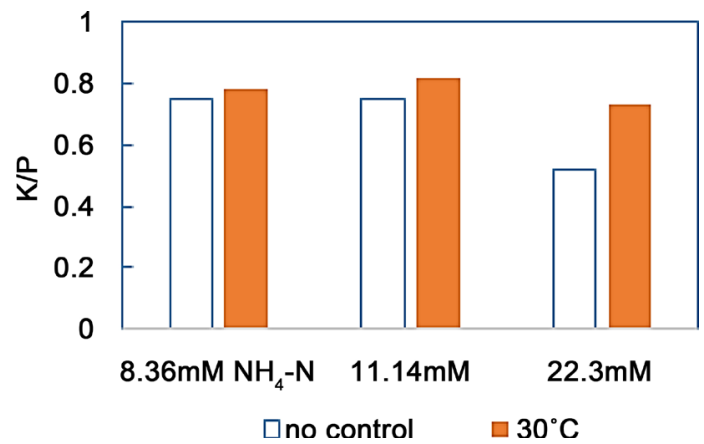

Figure 7. Effects of the initial ammonium concentration on the K/P ratio in precipitate dosage $\mathrm{Mg} / \mathrm{P}=1$ at $\mathrm{pH} 11,2$ hours operation.

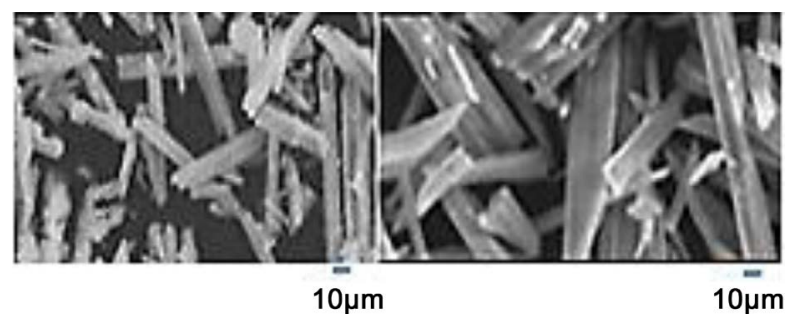

Room temperature $30^{\circ} \mathrm{C}$

Figure 8. Effects of temperature on the surfaces of the crystals formed at $\mathrm{NH}_{4}: 8.3 \mathrm{mM}$.

initial ammonium concentration on the K/P ratio are shown in Figure 7.

Electron microscopy photographs of the crystals produced at initial ammonium concentrations of between $0 \mathrm{mM}$ and $22.4 \mathrm{mM}$ are shown in Figure 8. In our simple batch tests, ammonium concentrations up to about $5 \mathrm{mM}$ did not affect the formation of MPP, but higher concentrations caused the K/P molar concentration ratios of the crystals to be $<1$. Initial ammonium concentrations of $8.36 \mathrm{mM}$ and $11.4 \mathrm{mM}$ gave crystals with $\mathrm{K} / \mathrm{P}$ ratios of $0.75-0.82$, but the differences between the ratios found when the tests were performed at room temperature and $30^{\circ} \mathrm{C}$ were small.

An initial ammonium concentration of $22.3 \mathrm{mM}$ gave crystals with a $\mathrm{K} / \mathrm{P}$ ratio of 0.73 , but the ratio was only 0.52 when the test was performed at room temperature. It is therefore possible to decrease the effects of the presence of ammonium even at high ammonium concentrations by aerating and stirring the solution and controlling the temperature of the system. Even though the production of MPP 
was affected by the higher ammonium concentrations, needle-like crystals were found in the precipitate formed at each ammonium concentration that was tested.

\subsection{Effects of Sulfate on the Formation of MPP}

The effects of sulfate on the components of the solutions and precipitate and an electron micrograph of the precipitate are shown in Figure 9 and Figure 10. We added nitrate to the wastewater with the compositions shown in Figure 2 to investigate the effect of the presence of nitrate on the system. The tests were performed at nitrate concentrations of $0 \mathrm{mM}, 4.02 \mathrm{mM}$ and $8.06 \mathrm{mM}$. The decrease in the concentration of nitrate ion in the liquid is almost unchanged at $0.1 \mathrm{mM}$. The ratio of $\mathrm{K}$ to $\mathrm{P}$ in the crystal is also almost unchanged at 1: 1 , and no difference in shape can be seen in the SEM photograph. From these points, it is considered that nitrate is no effect on MPP production.

The effects of sulfate on the components of the solutions and precipitate and an electron micrograph of the precipitate are shown in Figure 11 and Figure 12. We added sulfate to the wastewater with the compositions shown in Figure 2 to investigate the effect of the presence of sulfate on the system. The tests were performed at sulfate concentrations of $0 \mathrm{mM}, 1.02 \mathrm{mM}, 2.04 \mathrm{mM}$, and $3.06 \mathrm{mM}$. The white precipitate that was produced when the initial $\mathrm{SO}_{4}^{2-}$ concentration in the wastewater was $3.06 \mathrm{mM}$ was analyzed by EDS and was found to contain $36.0 \% \mathrm{PO}_{4}-\mathrm{P}, 18.4 \% \mathrm{~K}$, and $45.6 \% \mathrm{Mg}$. Little evidence of a sulfur component peak was found. Needle-like crystals were found at all of the sulfate ion concentrations that were tested. We therefore concluded that sulfate is not incorporated as a sulfur-containing compound in the crystals but inhibits MPP crystallization. No previous studies of the effects of $\mathrm{SO}_{4}^{2-}$ on MPP crystallization have been described,

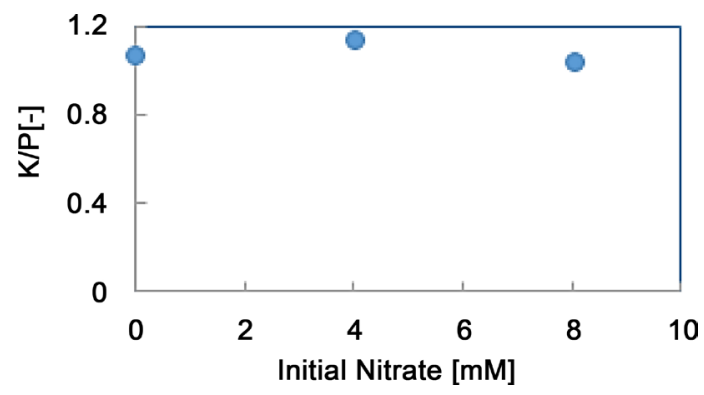

Figure 9. Effects of the initial nitrate concentration the K/P ratio.
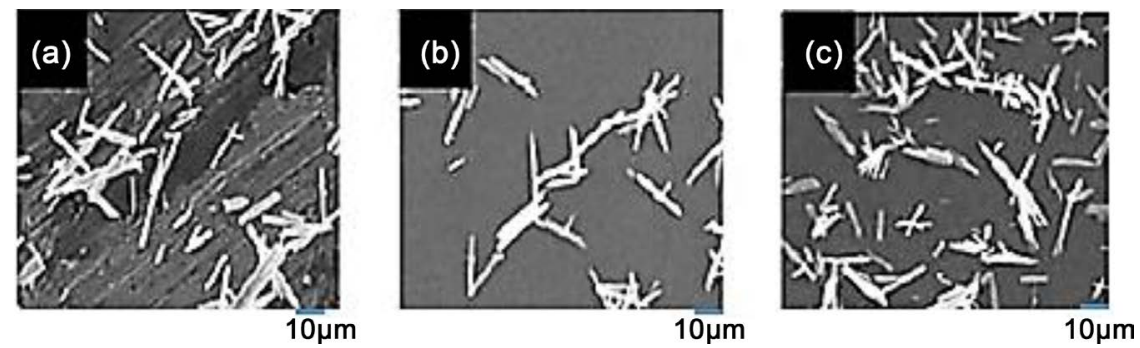

Figure 10. Effects of the nitrate concentration on the crystal on surfaces ((a) $0 \mathrm{mM}$, (b) $3.68 \mathrm{mM},(\mathrm{c}) 7.35 \mathrm{mM})$. 

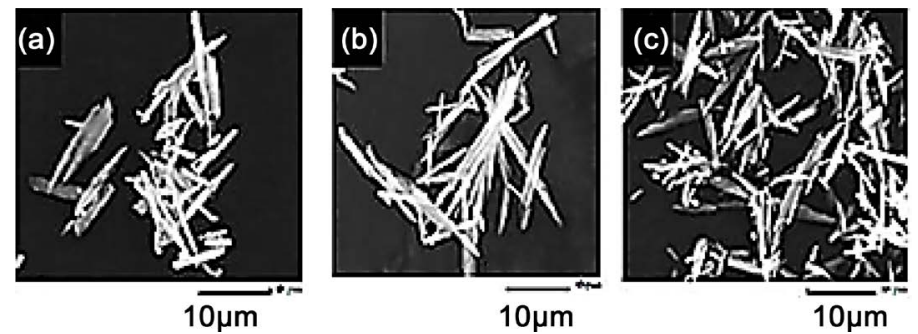

Figure 11. Effects of the initial sulfate concentration the K/P ratio.

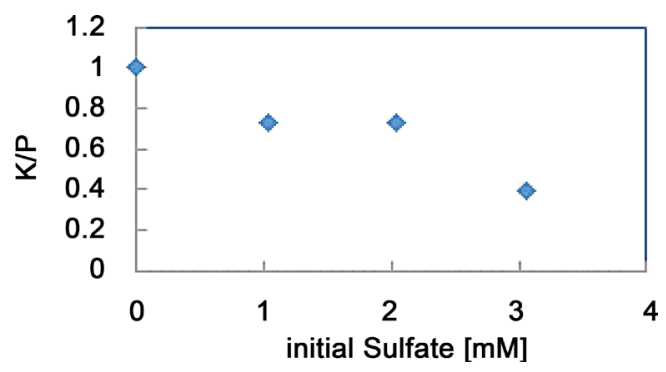

Figure 12. Effects of the sulfate concentration on the crystal on surfaces ((a) $1.02 \mathrm{mM}$, (b) $2.04 \mathrm{mM},(\mathrm{c}) 3.06 \mathrm{mM}$ ).

but MAP production has been found to be affected by the presence of $\mathrm{SO}_{4}^{2-}$ at a concentration of $1300 \mathrm{mg} / \mathrm{L}(13.54 \mathrm{mM})$ [13]. It appears that the production of MPP is affected by the presence of $\mathrm{SO}_{4}^{2-}$ in the same way.

\section{Conclusion}

The aim of the study was to further improve livestock wastewater treatment and the recycling of phosphorous resources. The MPP crystallization process was applied to model wastewater containing $25.6 \mathrm{mM}$ potassium, $6.5 \mathrm{mM}$ phosphorus, and $5.6 \mathrm{mM}$ ammonium at $\mathrm{pH} 11$ using a $\mathrm{Mg}$ dosage equimolar with the $\mathrm{P}$ concentration. Crystals containing equimolar K/P ratios were obtained after $2 \mathrm{~h}$ of continuous treatment. Small amounts of ammonium and sodium were found in the crystals. Nitrate did not affect the K/P ratio, but ammonia and sulfate did affect the ratio, $1 \mathrm{mM}$ sulfate in particular decreasing the $\mathrm{K} / \mathrm{P}$ ratio to 0.7 .

\section{Acknowledgements}

This work was supported by JSPS KAKENHI (grant no. 15K00605).

\section{References}

[1] Kuroda, A., Takiguchi, N., Kato, J. and Ohtake, H. (2005) Development of Technologies to Save Phosphorus Resources in Response to Phosphate Crisis. Journal of Environmental Biotechnology, 4, 87-94. (in Japanese)

[2] Hirasawa, I., Tanaka, T. and Iwai, N. (1983) Studies on Phosphorus Removal by Contact Crystallization from Wastewater. Japan Journal of Water Pollution Re search, 6, 229-235. (in Japanese)

[3] Kaan, Y. and Zehra, S.-Z. (2009) Recovery of Ammonium Nitrogen from the Effluent of UASB Treating Poultry Manure Wastewater by MAP Precipitation as a Slow Release Fertilizer. Journal of Hazardous Materials, 166, 260-269. 
https://doi.org/10.1016/j.jhazmat.2008.11.025

[4] Sibel, U.-D. and Maazuza, O. (2009) Removal of Ammonium and Phosphate from the Supernatant of Anaerobically Digested Waste Activated Sludge by Chemical Precipitation. Bioresource Technology, 100, 3236-3244.

https://doi.org/10.1016/j.biortech.2009.02.030

[5] Song, Y-H., Qiu, G.-L., Yuan, P., Cui, X.-Y., Peng, J.-F., Zeng, P., et al. (2011) Nutrients Removal and Recovery from Anaerobically Digested Swine Wastewater by Struvite Crystallization without Chemical Additions. Journal of Hazardous Materials, 190, 140-149. https://doi.org/10.1016/j.jhazmat.2011.03.015

[6] Suzuki, K., Tanaka, Y., Kuroda, K., Hanajima, D. and Fukumoto, Y. (2005) Recov ery of Phosphorus from Swine Wastewater through Crystallization. Bioresource Technology, 96, 1544-1550. https://doi.org/10.1016/j.biortech.2004.12.017

[7] Suzuki, K., Tanaka, Y., Kuroda, K., Hanajima, D., Fukumoto, Y., Yasuda, T. and Waki, M. (2007) Removal and Recovery of Phosphorus from Swine Wastewater by Demonstration Crystallization Reactor and Struvite Accumulation Device. Bioresource Technology, 98, 1573-1578. https://doi.org/10.1016/j.biortech.2006.06.008

[8] Xu, K., Li, J., Zheng, M., Zhang, C., Xie, T. and Wang, C. (2015) The Precipitation of Magnesium Potassium Phosphate Hexahydrate for P and K Recovery from Synthetic Urine. Water Research, 80, 71-79. https://doi.org/10.1016/j.watres.2015.05.026

[9] Xu, K., Wang, K., Wang, X. and Qian, Y. (2012) Laboratory Experiments on Simultaneous Removal of K and P from Synthetic and Real Urine for Nutrient Recycle by Crystallization of Magnesium-Potassium-Phosphate-Hexahydrate in a Draft Tube and Baffle Reactor. Chemosphere, 88, 219-223.

https://doi.org/10.1016/j.chemosphere.2012.02.061

[10] Ymaguchi, S., Ohura, S., Harada, H., Akagi, K., Mitoma, Y., Kawakita, H. and Biswas, B.K. (2013) Simultaneous Crystallization of Phosphate and Potassium as Magnesium Potassium Phosphate Using Bubble Column Reactor with Draught Tube. Journal of Environmental Chemical Engineering, 1, 1154-1158. https://doi.org/10.1016/j.jece.2013.08.032

[11] Tanaka, T. and Miyamaoto, T. (2013) Simultaneous Recovery of Phosphorus and Po tassium from Livestock by an Electrolytic Crystallization Method. Journal of Japan Society of Civil Engineers Series G Environmental Research, 69, 1-9.(in Japanese)

[12] Eugene, W., Rice, R.B.B., Andrew, D.E. and Lenore, S.C. (2012) Standard Methods for Examination of Water and Wastewater. 21st Edition, American Public Health Association, Washington DC.

[13] Shih, Y.-J., Ruffel, M.A.R., Daniel, G.de L.M., Huang, Y.-H. and Lu, M.-C. (2017) Recovery of Phosphorus from Synthetic Wastewaters by Struvite Crystallization in a Fluidized-Bed Reactor: Effects of $\mathrm{pH}$, Phosphate Concentration and Coexisting Ions. Chemosphere, 173, 466-473. https://doi.org/10.1016/j.chemosphere.2017.01.088

[14] Akagi, K., Teranaka, R., Harada, H., Katayama, M.Y. and Biswas, B.K. (2016) Gen eration of Magnesium Potassium Phosphate from Synthetic Livestock Wastewater Containing High Levels Phosphorus and Potassium. Journal of Water Pollution and Treatment, 1, 1-7. 